\title{
Notes on the Rate of Growth of Tellina tenuis da Costa in the Firth of Clyde.
}

\author{
By
}

A. C. Stephen, B.Sc.,

Royal Scottish Museum, Edinburgh, and at the Marine Station, Millport.

With 5 Figures in the Text.

\section{CONTENTS.}

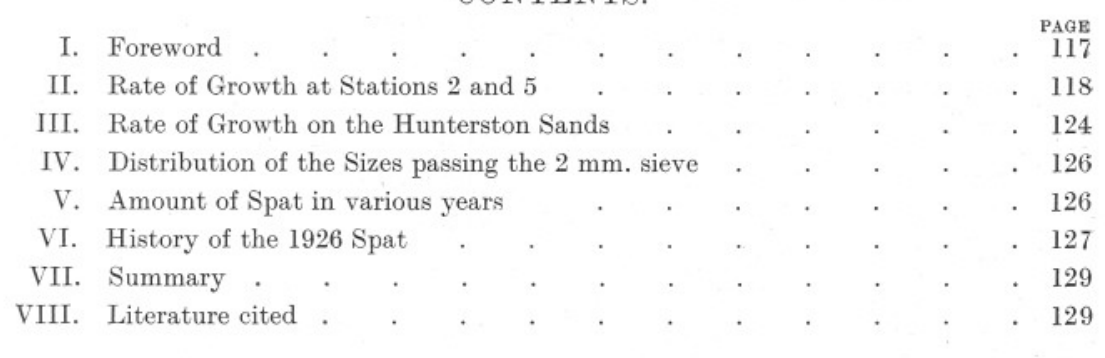

\section{FOREWORD.}

THE material on which the present paper is based was collected from the Millport Marine Biological Station. I am indebted to the Superintendent, Mr. Elmhirst, for facilities for making the collections.

The biology of Tellina tenuis in the Cumbrae and neighbourhood was investigated during the autumn of 1926 and in 1927 (2), and the present paper is a direct continuation of that work. On several points in the earlier work, especially on the rate of growth of the species, it was felt that confirmatory evidence was necessary. A comparison of the sizefrequency curves for the autumn of 1926 and 1927 showed that while on the 1926 curve there were only two modes, there were three on the 1927 curve, and that the mid mode of 1927 fell midway between those of 1926. This meant either, that rate of growth of the intermediate group in 1927 had been only half of that of the corresponding group in the previous year, or that on the 1926 curve one or more year groups were unrepresented. The latter explanation was considered at the time to be the more satisfactory one, and the work of the present year seems to confirm that view.

In the earlier investigation samples were collected at five intertidal 
stations, and at several stations below L.W.M., but for the present study it was not deemed necessary to re-examine all these, and regular collecting was restricted in the intertidal zone to Stations 5 and 2 (at L.W.M. springs and 40 yards below H.W.M. neaps respectively), and below L.W.M. to Stations 6 and 7 (2 and 3 fathoms respectively). In the earlier investigation the amount of sand sieved at the intertidal stations was a standard cut of a $\frac{1}{4}$ sq. metre dug to a depth of about $15 \mathrm{~cm} .{ }^{*}$ but during 1928, in addition to this standard cut, extra cuts were sieved to increase the collections, especially for the older groups. For comparison with Kames Bay one station on the Hunterston Sands was examined. All stations were visited three times during the year, in March, June, and the end of September.

\section{Rate of Growth at Stations 2 and 5.}

Stn. 5 (Figs. 1-2. Table VI).

A comparison of the figures for October, 1927, with those of March, 1928, shows that, as in the previous year, there had been no growth during the winter months. There had been, however, a considerable mortality amongst the smallest individuals (1927 spat), the proportion of the population at $3 \mathrm{~mm}$. having fallen from $20 \cdot 7 \%$ to $14.8 \%$.

By the beginning of June, 1928, only a little growth was apparent, the mode at $7 \mathrm{~mm}$. having shifted to $8 \mathrm{~mm}$. and that at $11 \mathrm{~mm}$. to $12 \mathrm{~mm}$., but there was no sign of any growth amongst the smaller sizes, the mode remaining at $3 \mathrm{~mm}$.

By the end of September, 1928, the mode at $8 \mathrm{~mm}$. in June had moved to $9 \mathrm{~mm}$., but the group represented by the mode at $12 \mathrm{~mm}$. in June, although still present, no longer formed a distinct group.

The greatest change had taken place amongst the smaller sizes in which the mode at $3 \mathrm{~mm}$. in June had moved to $6 \mathrm{~mm}$. and the young spat had appeared at $3 \mathrm{~mm}$.

Compared with 1927 growth had been rather less and, amongst the smaller sizes, more erratic. For example, in 1927 the mode at $3 \mathrm{~mm}$. in April moved to $5 \mathrm{~mm}$. in June and to $7 \mathrm{~mm}$. by the beginning of October, while in 1928 the mode at $3 \mathrm{~mm}$. in March was still at the same figure in June, but reached $6 \mathrm{~mm}$. by the end of September.

On the size-frequency curve for September, 1928, there are three modes at $3 \mathrm{~mm} ., 6 \mathrm{~mm}$., and $9 \mathrm{~mm}$., representing respectively :

$$
\begin{array}{llllll}
0+\operatorname{group} & \cdot & \cdot & \cdot & . & 1928 \text { spat. } \\
1+\quad, & \cdot & \cdot & \cdot & \cdot & 1927, \\
2+\quad, & \cdot & \cdot & \cdot & . & 1926,
\end{array}
$$

\footnotetext{
* Contracted in the rest of the paper to " $\frac{1}{4} \mathrm{sq}$. m."
} 
as we know from measurements since September, 1926. On the curve for October, 1927, there were also three modes at $3 \mathrm{~mm} ., 7 \mathrm{~mm}$., and $11 \mathrm{~mm}$. respectively, which were considered to represent the 1927 spat, 1926 spat, and 1924 spat respectively (2, p. 690).

\section{Stn. 5}

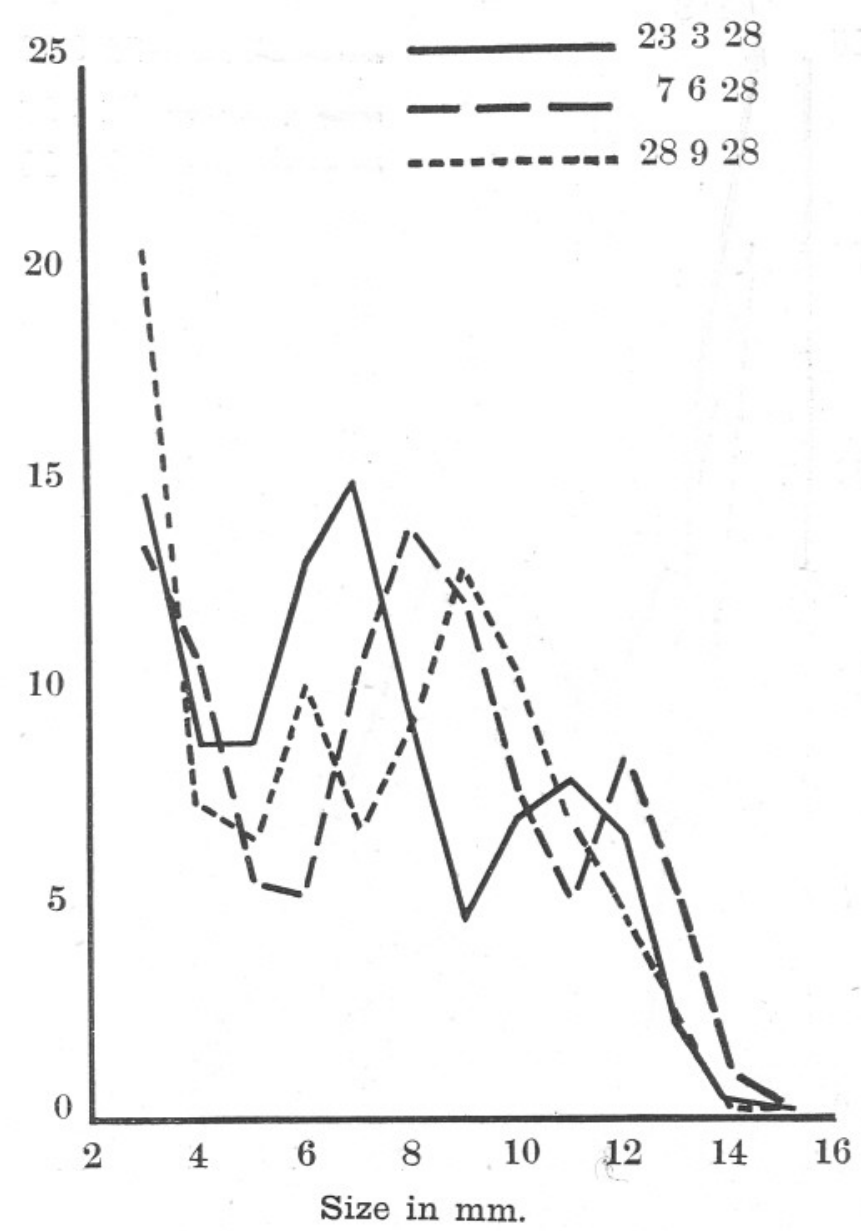

Fig. 1.-Graph showing the percentage (ordinate) of the catch at each mm. for Stn. 5 in March, June and Sept., 1928.

The view that a year group (1925 spat) was unrepresented on the curve for 1926 seems justified when we consider that the rate of growth during 1928 was of the same order as during 1927 and that there was in September, 1928, a mode at $9 \mathrm{~mm}$., the figure at which, in the earlier paper, it was. 
considered that a year group should have been present on the curve for September, 1926 (2, p. 690).

The various year groups did not form equal proportions of the population. Since 1926 the spat of that year has continued as a dominant

\section{Stn 5}

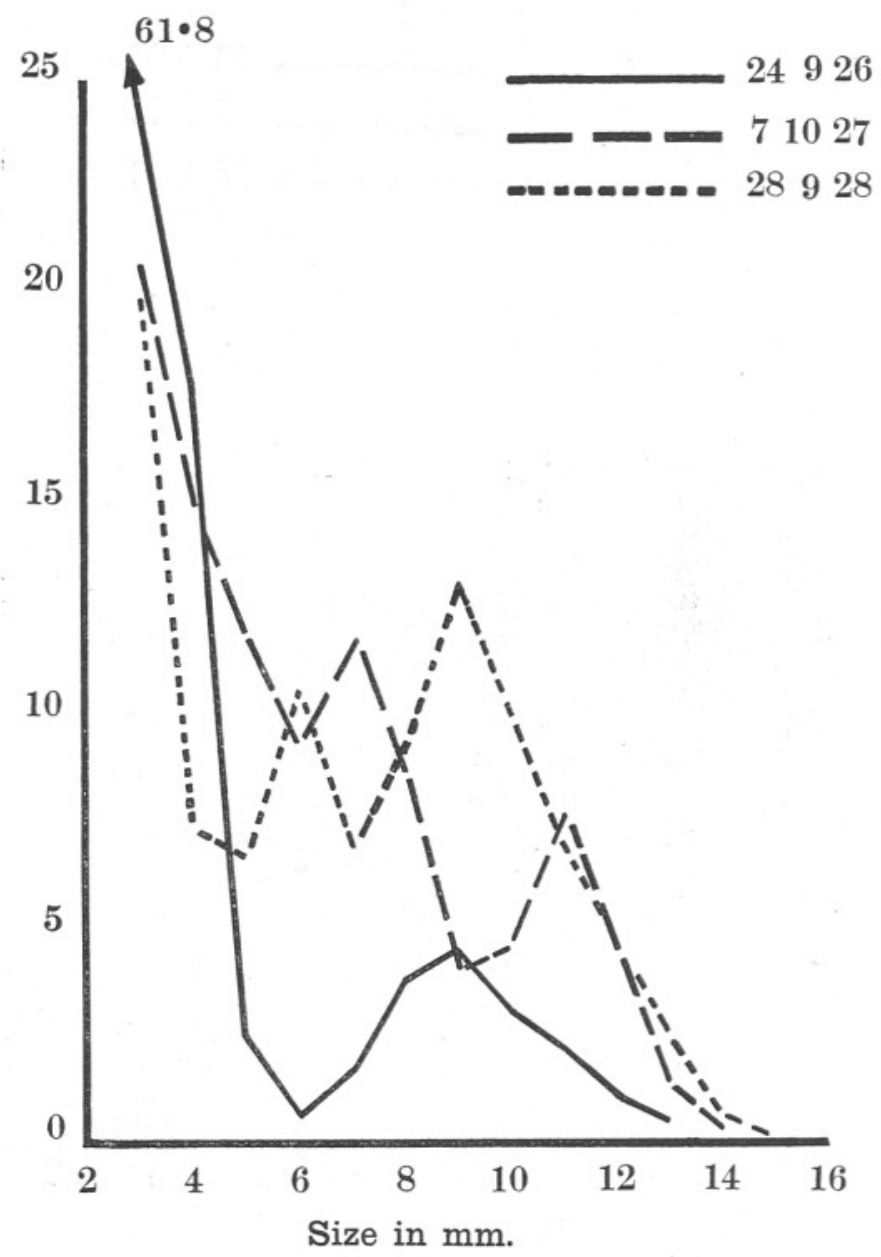

FIG. 2.-Graph showing the percentage (ordinate) of the catch at each mm. for Stn. 5 in Sept. 1926, Oct. 1927, and Sept. 1928.

group, and as the $2+$ group in September, 1928, even with the natural rate of mortality of two years, it formed a large proportion of the population (Fig. 2). If we take the numbers from $8 \mathrm{~mm}$. to $11 \mathrm{~mm}$. 
as representing the group, the proportion was $40 \%$ and the actual numbers per " $\frac{1}{4}$ sq. m." 304 .

These figures also indicate that in Kames Bay the species can be subject to little interference, for it is unlikely that if this were to any extent a

Stn. 2 23328
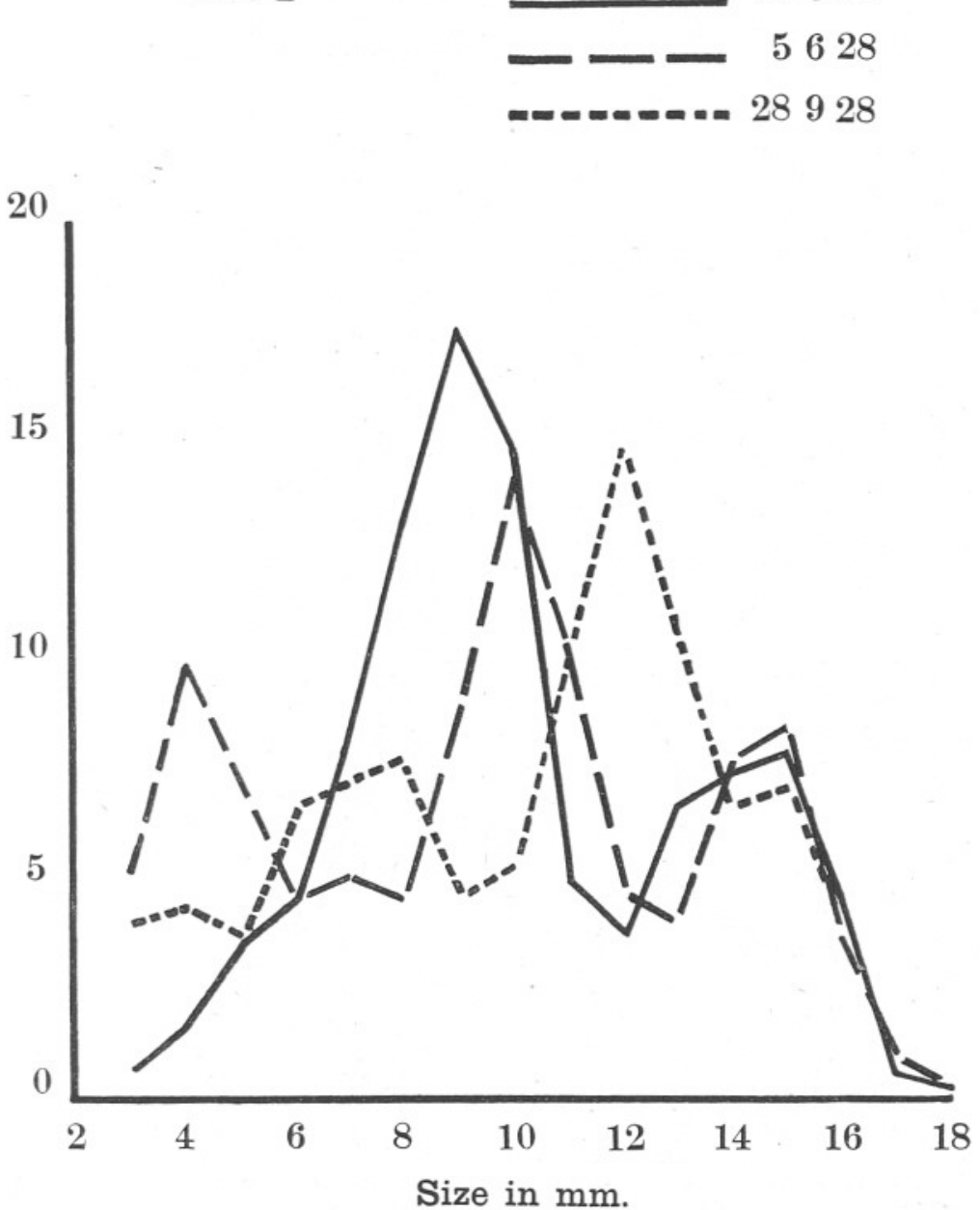

FIG. 3.-Graph showing the percentage (ordinate) of the catch at each mm. for Stn. 2 in March, June and Sept. 1928.

feeding-ground for fish the 1926 spat could have survived in such numbers.

Stn. 2 (Figs. 3-4. Table VI).

As at Station 5, there was no growth during the winter months, the size-frequency curve for March, 1928, being very similar to that of October, 
1927. Again, the maximum concentration of the individuals $3 \mathrm{~mm}$. in length occurred in late spring, not in autumn as at Station 5.

Stn. 2

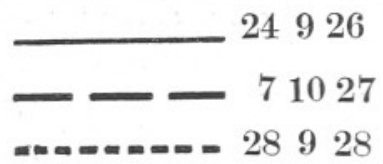

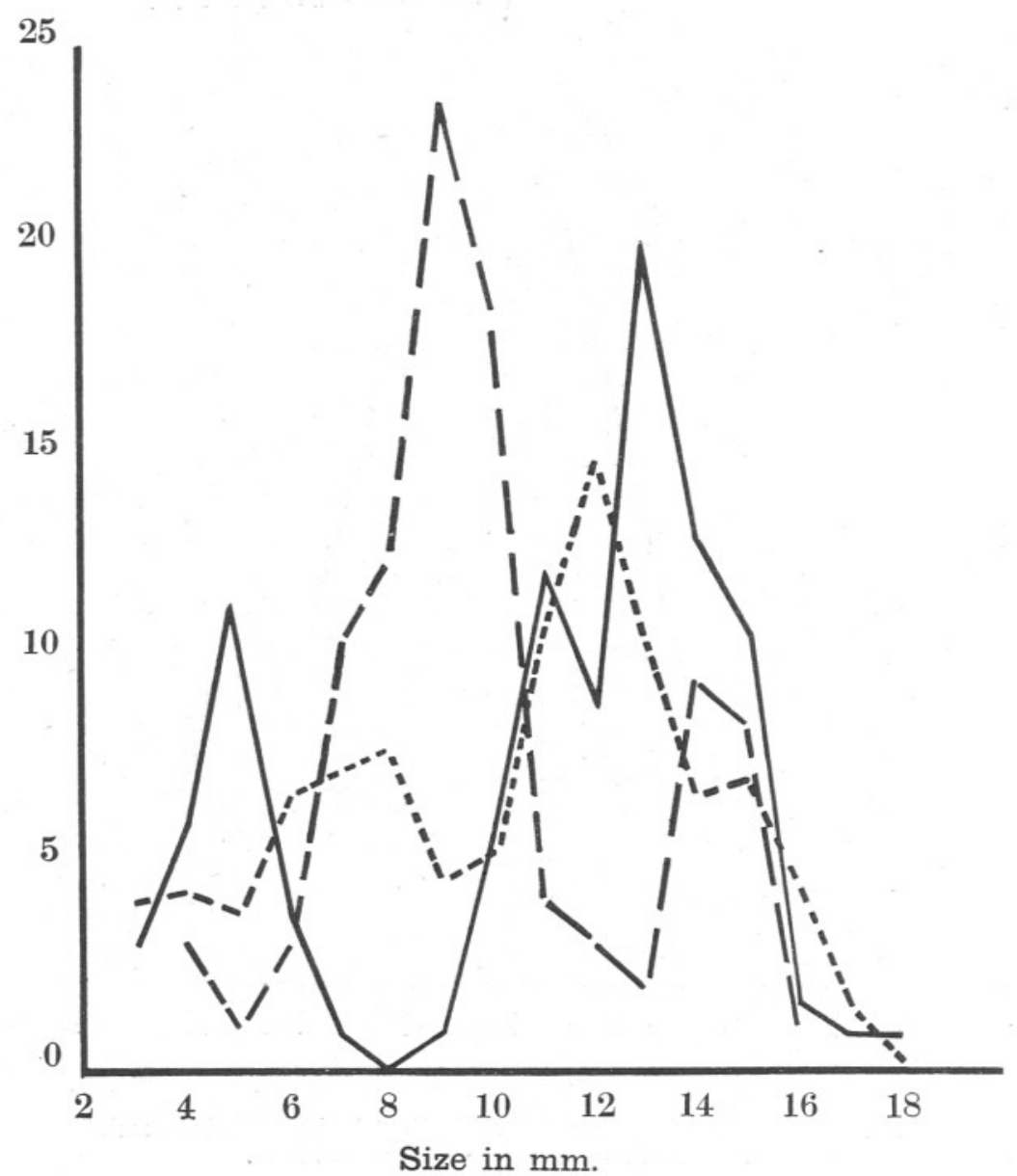

Fig. 4.-Graph showing the percentage (ordinate) of the catch at each mm. for Stn. 2 in Sept. 1926, Oct. 1927 and Sept. 1928.

On the size-frequency curve for March, 1928, there were modes at $9 \mathrm{~mm}$. and $15 \mathrm{~mm}$. By June that at $9 \mathrm{~mm}$. had moved to $10 \mathrm{~mm}$., but that at $15 \mathrm{~mm}$. remained at the same figure. At the other end of the 
curve the spat of 1927 was showing as a distinct group at $4 \mathrm{~mm}$. By the end of September the mode at $4 \mathrm{~mm}$. had moved to $8 \mathrm{~mm}$., that at $10 \mathrm{~mm}$. to $12 \mathrm{~mm}$., while that at $15 \mathrm{~mm}$. remained stationary.

Compared with 1927 growth was rather less, the modes for 1928 being about $1 \mathrm{~mm}$. behind the corresponding ones for 1927 .

In 1927 also the rate of growth from March to June was greater than that from June to the beginning of October, but in 1928 the position was reversed.

The results at this station again confirm the view of a missing year group on the curve for 1926, the rate of growth during 1928 having been of the same order as in 1927.

The 1926 spat was a prominent group at this station, as at Station 5. If we take the figures from $10 \mathrm{~mm}$. to $15 \mathrm{~mm}$. as representing it, the proportion of the population belonging to it was $52.5 \%$ and the actual numbers were 108 per " $\frac{1}{4}$ sq. m."

\section{Stn. 6 (Table VI).}

The collection made at this station in the end of September, 1928, was similar to those of the preceding years. The individuals were all very small and few exceeded $7 \mathrm{~mm}$. in length.

There were no signs of any growth or of year groups as at Stations 2 and 5. There had been, however, a steady decrease from 325 in September, 1926, to 128 in September, 1928, per $20 \mathrm{~cm}$. cube, as the following table shows.

\section{TABLE I.}

Table showing the decrease in the numbers of Tellina tenuis per $20 \mathrm{~cm}$. cube at Station 6 from September, 1926, to September, 1928.

\begin{tabular}{|c|c|c|c|c|}
\hline Date. & & & & $\begin{array}{c}\text { No. of } \\
\text { Tellina tenuis }\end{array}$ \\
\hline 6.10 .26 & . & . & . & 327 \\
\hline 13.4 .27 & . & . & . & 355 \\
\hline 13.8 .27 & . & . & . & 254 \\
\hline 8.10 .27 & . & . & . & 194 \\
\hline 23.3 .28 & . & . & . & 167 \\
\hline 28.9 .28 & . & . & . & . 128 \\
\hline
\end{tabular}

\section{StN. 7 (Table VI).}

Again, as on previous occasions, the individuals at this station were only of very small size, the majority ranging from $3 \mathrm{~mm}$. to $6 \mathrm{~mm}$. As at Station 6 , there had been practically no signs of growth during the whole year, but again there had been a very heavy mortality as the following table shows. 
TABLE II.

Table showing the decrease in the numbers of Tellina tenuis per $20 \mathrm{~cm}$. cube during 1928.

Date.

8.10 .27

23.3 .28

28.9.28
No. of Tellina tenuis.

143

66

18

The results from Stations 1 to 5, that is from that part of the range of the species from H.W.M. to L.W.M., are straightforward. The sizefrequency curves show modes which move forward regularly and the course of events is orderly and logical.

At Stations 6 to 8 , that is from that part of the range of the species below L.W.M., the results do not fit into the same scheme. When first examined in September, 1926, the specimens of Tellina tenuis were all fairly small (2, p. 701$)$, and they appear to have remained at practically the same size ever since. Now elsewhere we find the species below L.W.M., although only in small numbers, but the size of the individual is often much greater than here. What, then, is the explanation of the state of affairs in Kames Bay? The most satisfactory explanation is that in the summer and autumn of 1926 huge numbers of spat settled on the ground from Stations 6 to 8 , causing overcrowding to such an extent that the food supply has proved insufficient. Under such circumstances a species, after holding the ground for some time would, in the natural course of events, begin to die off, and this is exactly what has been taking place to a very marked extent during the present year (Tables I and II).

\section{Rate of Growth of Tellina tenuis on the Hunterston Sands.}

It was decided to make an exact comparison during 1928 between the rate of growth of Tellina tenuis in Kames Bay and in one of the other sands. A station near L.W.M. on the Hunterston Sands, Ayrshire Coast, was chosen and was examined at the same times as Kames Bay.

\section{Hunterston Sands at Perch (Fig. 5. Table VII).}

On the size-frequency curves there were in April two modes at $3 \mathrm{~mm}$. and $9 \mathrm{~mm}$. By June that at $3 \mathrm{~mm}$. had moved to $5 \mathrm{~mm}$. and that at $9 \mathrm{~mm}$. to $10 \mathrm{~mm}$. By the end of September the curve had greatly changed, for, as at Station 5, the group represented by the $10 \mathrm{~mm}$. mode in June 
had practically disappeared. Now this result was not due to insufficient sampling but represented the actual condition of affairs, for in view of such a marked change the matter could not be left undecided, and two repeat samplings were made, with exactly the same result.

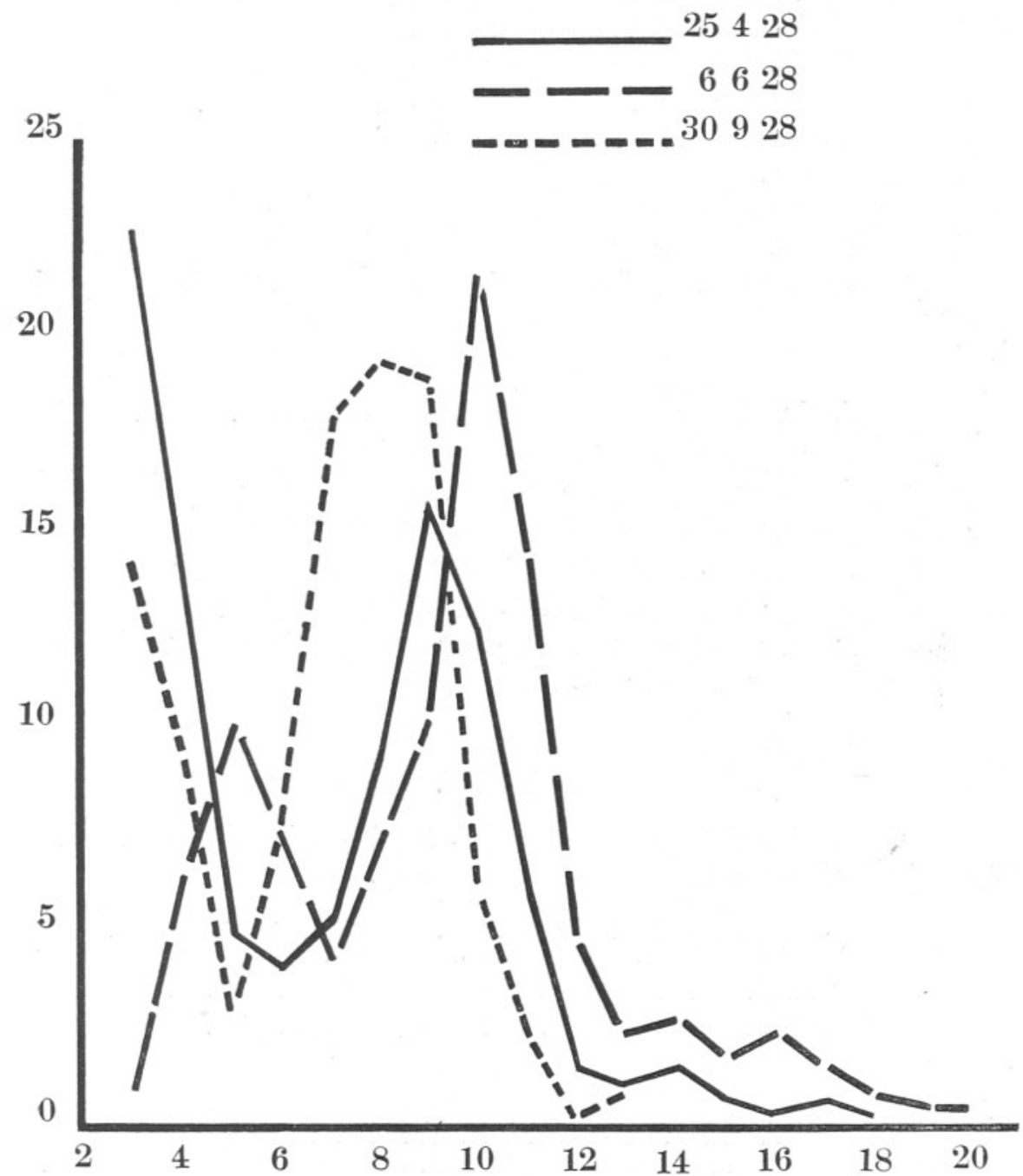

FIG. 5.-Graph showing the percentage (ordinate) of the catch at each $\mathrm{mm}$. for the Hunterston Sands at L.W.M. in April, June and Sept. 1928.

To return to the curve, the mode at $5 \mathrm{~mm}$. in June had moved to $8 \mathrm{~mm}$. and the new spat had appeared at $3 \mathrm{~mm}$. in September. The two modes on the September curve represent the $0+$ group (1928 spat) at $3 \mathrm{~mm}$. 
and the $1+$ group (1927 spat) at $8 \mathrm{~mm}$. The $2+$ group (1926 spat), which is still the dominant year group in Kames Bay and was, till June, here also, has gone. When picking over the samples the empty valves, whole and therefore not taken by fish, were found in large numbers, but what was the cause of the heavy mortality here, and to a lesser extent at Station 5 in Kames Bay, was not apparent.

If we take the April curve as roughly corresponding to the size-frequency distribution at the end of the previous autumn, growth, as in Kames Bay, has been rather less in 1928, the second mode being at $8 \mathrm{~mm}$. as against $9 \mathrm{~mm}$. last year.

The position of the mode at $8 \mathrm{~mm}$. indicates that the rate of growth at this station is of the same order as that at Stations 2 or 3 in Kames Bay, and not as at Station 5, as the position on the beach would lead us to suppose.

\section{Distribution of Sizes passing the 2 m. Sieve.}

So far we have only dealt with the specimens retained by the $2 \mathrm{~mm}$. sieve. In the earlier investigation the distribution and relative frequency of the sizes passing the $2 \mathrm{~mm}$. sieve but retained by the $1 \mathrm{~mm}$. sieve were also dealt with, and for comparison a similar set of observations was made at Stations 2, 5, 6, and 7 in 1928. Compared with 1927 there has been a marked reduction in the numbers at all stations by the end of 1928, as the following table shows.

\section{TABLE III.}

Table showing the numbers of Tellina tenuis passing the $2 \mathrm{~mm}$. sieve but retained by the $1 \mathrm{~mm}$. sieve in Kames Bay.

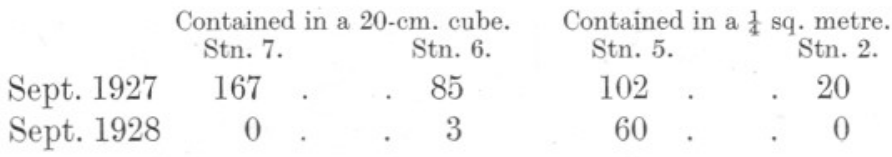

\section{Amount of Spat in Various Years.}

There is good evidence that the spat which settled on the bottom and survived until the autumn varied during the years 1926-8. The year 1926 stands out as one of unusual abundance. If we consider the individuals of $3 \mathrm{~mm}$. and $4 \mathrm{~mm}$. in the end of September as representing the spat, the numbers per $\frac{1}{4} \mathrm{sq}$. m. at Stations 2 and 5 for each year were as follows. 


\section{TABLE IV.}

Table showing the numbers of specimens $3 \mathrm{~mm}$. and $4 \mathrm{~mm}$. in length at Stations 5 and 2 in September of each year per $\frac{1}{4} \mathrm{sq}$. $\mathrm{m}$.

\begin{tabular}{|c|c|c|c|c|}
\hline 192 & & $\begin{array}{c}\text { Stn. } 5 . \\
. \quad 655\end{array}$ & . . & $\begin{array}{c}\text { Stn. } 2 . \\
12\end{array}$ \\
\hline 1927 & & . 272 & $\ldots$ & 13 \\
\hline 208 & & . 213 & $\ldots$ & 26 \\
\hline
\end{tabular}

So far as the collections made by the $2 \mathrm{~mm}$. sieve are concerned 1927 and 1928 seem to be about equal, but when the figures in Table III are taken into consideration 1928 appears the poorer.

\section{History of the 1926 Spat.}

It has already been pointed out how the 1926 spat has survived as a dominant group, and it is possible to trace its history since 1926.

The group was found as spat in September, 1926, and was present in large numbers from Station 7 to half-tide, and in small numbers to H.W.M.

In September, 1928, below L.W.M. it still remained on the ground, but showed little growth, and had steadily declined in numbers. At Station 7 a few remained and the numbers had fallen to a third at Station 6 .

At, and above, L.W.M. the modes remained at a standstill during the winter months, but showed progress during the summer months, the shift of the mode being least at Station 5 and proportionately greater at each station nearer H.W.M. The halts and progress of the modes are clearly seen in Table $\mathrm{V}$.

\section{TABLE V.}

Table showing the position of the modes of the 1926 spat, from September, 1926, to September, 1928, for each time of collecting, for Stations 2 and 5 .

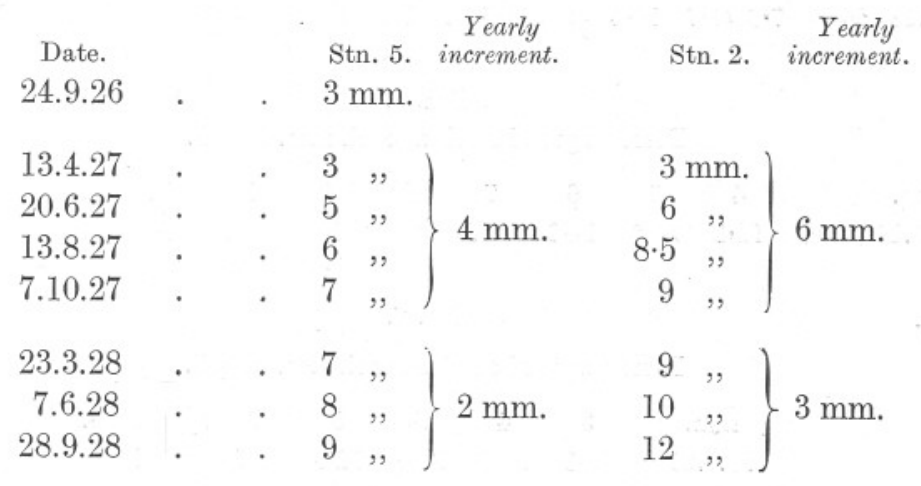


In 1927 the mode shifted from $3 \mathrm{~mm}$. to $7 \mathrm{~mm}$. at Station 5 and from $3 \mathrm{~mm}$ to $9 \mathrm{~mm}$. at Station 2. During 1928 the shift at Station 5 was from $7 \mathrm{~mm}$. to $9 \mathrm{~mm}$., and at Station 2 from $9 \mathrm{~mm}$. to $12 \mathrm{~mm}$. In other words, the movement during 1928 was exactly half of that during 1927 at both stations. This result is in accord with that which Orton (1) has found for Cardium edule. In that species, for four years, each annual increment was approximately half of the preceding year.

If, in the case of the Lamellibranchs, it can be assumed that the annual increment is even approximately half that of the preceding year, an important point is established, which may give a means of estimating the age of the numerous small, but from the economic point of view important, species. In these species it might be possible to measure the first full year's increment, but it would probably be very difficult to follow subsequent growth.

\section{TABLE VI.}

Stn. 2.

Percentages of eatch at each mm. length.

$\begin{array}{rrrrrrrrrrrrrrrrrrr}\text { mm. } & 3 & 4 & .5 & 6 & 7 & 8 & 9 & 10 & 11 & 12 & 13 & 14 & 15 & 16 & 17 & 18 \begin{array}{r}\text { Total } \\ \text { speci- } \\ \text { mens. }\end{array} \\ 23.3 .28 & 0 \cdot 7 & 1 \cdot 6 & 3 \cdot 7 & 4 \cdot 7 & 8 \cdot 0 & 13 \cdot 1 & 17 \cdot 5 & 14 \cdot 8 & 5 \cdot 0 & 3 \cdot 8 & 6 \cdot 7 & 7 \cdot 4 & 7 \cdot 9 & 4 \cdot 6 & 0 \cdot 5 & 0 \cdot 2 & 674 \\ 5.6 .28 & 5 \cdot 1 & 9 \cdot 8 & 7 \cdot 2 & 4 \cdot 4 & 5 \cdot 1 & 4 \cdot 7 & 9 \cdot 0 & 13 \cdot 9 & 10 \cdot 4 & 4 \cdot 8 & 4 \cdot 1 & 7 \cdot 7 & 8 \cdot 4 & 3 \cdot 9 & 0 \cdot 9 & 0 \cdot 2 & 662 \\ 28.9 .28 & 4 \cdot 1 & 4 \cdot 4 & 3 \cdot 8 & 6 \cdot 7 & 7 \cdot 3 & 7 \cdot 7 & 4 \cdot 7 & 5 \cdot 3 & 10 \cdot 7 & 14 \cdot 9 & 10 \cdot 5 & 6 \cdot 6 & 7 \cdot 3 & 4 \cdot 5 & 1 \cdot 4 & 0 \cdot 2 & 684\end{array}$

Stn. 5

Percentages of catch at each $\mathrm{mm}$. length.

$\begin{array}{rrrrrrrrrrrrrrrrr}\text { mm. } & 3 & 4 & 5 & 6 & 7 & 8 & 9 & 10 & 11 & 12 & 13 & 14 & 15 & \begin{array}{c}\text { Total } \\ \text { speci- } \\ \text { mens. }\end{array} \\ 23.3 .28 & 14 \cdot 8 & 8 \cdot 9 & 8 \cdot 9 & 13 \cdot 1 & 15 \cdot 1 & 10 \cdot 0 & 4 \cdot 8 & 7 \cdot 1 & 8 \cdot 0 & 6 \cdot 7 & 2 \cdot 3 & 0 \cdot 4 & 0 \cdot 1 & 2002 \\ 7.6 .28 & 13 \cdot 6 & 10 \cdot 9 & 5 \cdot 6 & 5 \cdot 3 & 10 \cdot 7 & 13 \cdot 9 & 12 \cdot 2 & 7 \cdot 7 & 5 \cdot 1 & 8 \cdot 7 & 5 \cdot 3 & 1 \cdot 2 & 0 \cdot 2 & 1351 \\ 28.9 .28 & 20 \cdot 6 & 7 \cdot 5 & 6 \cdot 7 & 10 \cdot 4 & 6 \cdot 8 & 9 \cdot 4 & 13 \cdot 1 & 10 \cdot 5 & 7 \cdot 0 & 4 \cdot 9 & 2 \cdot 5 & 0 \cdot 3 & 0 \cdot 2 & 1519\end{array}$

Stn. 6.

Percentages of catch at each mm. length.

$\begin{array}{cccccccccccc}\text { mm. } & 3 & 4 & 5 & 6 & 7 & 8 & 9 & 10 & 11 & 12 & \text { Total } \\ \text { specimens. }\end{array}$

Stn. 7 .

Percentages of catch at each mm. length.

$\begin{array}{ccccccc}\text { mm. } & 3 & 4 & 5 & 6 & 7 & \begin{array}{c}\text { Total } \\ \text { specimens. }\end{array} \\ 29.9 .28 & 32 \cdot 3 & 22 \cdot 6 & 29 \cdot 0 & 12 \cdot 9 & 3 \cdot 2 & 31\end{array}$




\section{Table VII.}

Hunterston Sands (at Perch).

Percentages of catch at each mm. length.

$\begin{array}{lllllllllllllll}\text { mm. } & 3 & 4 & 5 & 6 & 7 & 8 & 9 & 10 & 11 & 12 & 13 & 14 & 15 & 16\end{array}$

$\begin{array}{ll}11 & \\ \text { mens. } & \end{array}$

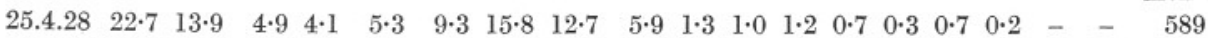

$\begin{array}{llllllllllllllllllll}6.6 .28 & 0.9 & 6 \cdot 3 & 10 \cdot 1 & 7 \cdot 5 & 4 \cdot 2 & 7 \cdot 3 & 10 \cdot 1 & 21 \cdot 8 & 14.5 & 4.9 & 2 \cdot 3 & 2.6 & 2 \cdot 1 & 2.3 & 1.4 & 0.7 & 0.5 & 0.5 & 427\end{array}$

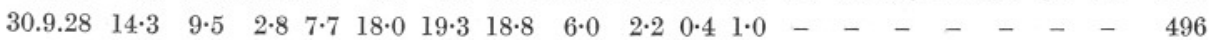

\section{SUMMARY.}

1. The present paper is a direct continuation of the work done at Millport during 1926 and 1927.

2. As before, Tellina tenuis showed no growth during the winter months.

3. As before, the rate of growth at L.W.M. was less than that near H.W.M.

4. Below L.W.M. there seemed to have been no growth during the year, but there had been a heavy mortality during 1928 .

5. Above L.W.M. the rate of growth during 1928 was of the same order as that of 1927, and the view that a year group was unrepresented on the 1926 curve seems justified.

6. At the end of September, 1928, the 1926 spat still formed a large and well-marked group.

7. The history of the 1926 spat is traced, and the annual increment found to be halved in succeeding years.

VIII. LITERATURE CITED.

1. Orton, J. H. Rate of Growth of Cardium edule. Jour. Mar. Biol. Assoc. New Series, Vol. XIV, No. 2, 1926.

2. Stephen, A. C. Notes on the Biology of Tellina tenuis. Jour. Mar.

Biol. Assoc. Vol. XV, No. 2, April, 1928. 
